\title{
A Música como Ferramenta de Otimização do Ensino Jurídico
}

\author{
Music as a Tool for Optimizing Legal Education
}

\author{
Pedro Faraco Neto
}

Universidade Pitágoras Unopar, Curso de Direito. PR. E-mail: pedrofaraconeto@hotmail.com.

\begin{abstract}
Resumo
O trabalho se propõe a discorrer sobre duas problemáticas: firmar o Direito como um sistema comunicativo e apontar qual ferramenta seria adequada para, por meio da faceta comunicativa do Direito, otimizar o seu ensinamento. Neste diapasão sabe-se que o ser humano é um ser de transcendência, isto é, está sempre buscando evoluir. Para isso faz uso da comunicação. Se comunicando, se transmite conhecimento e se evolui. Nada mais inato às pessoas. O Direito, criação humana, também faz uso da comunicação, uma vez que as pessoas devem respeitar a sua ínsita coerção. No Direito temos o comunicador - a lei ou o juiz; temos o destinatário - o cidadão; temos o conteúdo da comunicação - a determinação legal ou judicial; e temos o efeito buscado - o respeito à lei ou a decisão. Ocorre que na música, com as suas caraterísticas lúdica e estética, também se tem os mesmos elementos, quais sejam: comunicador, destinatário, conteúdo e efeito. E assim sendo, a música pode ser a ferramenta ideal para a divulgação e ensino do Direito, uma vez que por seu intermédio haverá uma maior aderência cognitiva dos postulados jurídicos a serem pedagogicamente difundidos. E como a música tem múltiplas facetas, a mesma pode abranger toda a complexidade do Direito, atingindo a todos em um despertar crítico distante do trivial ensino que se limita a reproduzir as leis e os julgados. Nesta esteira, descobre-se a música como poderosa ferramenta de ensino jurídico.
\end{abstract}

Palavras-chave: Direito. Música. Comunicação. Otimização. Ensino.

\begin{abstract}
The paper proposes to discuss two problems: to establish the law as a communicative system and to point out which tool would be appropriate to optimize the teaching through the communicative facet of the law. In this tuning fork it is known that the human being is a being of transcendence, that is, is always seeking to evolve. For this it makes use of communication. Communicating, transmitting knowledge and evolving. Nothing more innate to people. Law, human creation, also makes use of communication, since people must respect its inherent coercion. In law we have the communicator - the law or the judge; we have the recipient - the citizen; we have the content of the communication - the legal or judicial determination; and we have the desired effect-respect for the law or decision. It happens that in music, with its playful and aesthetic characteristics, also has the same elements, namely: communicator, recipient, content and effect. Therefore, music can be the ideal tool for the dissemination and teaching of law, since through it there will be a greater cognitive adherence to legal postulates to be pedagogically disseminated. And because music has multiple facets, it can encompass the full complexity of law, reaching everyone in a critical awakening far from the trivial teaching that merely reproduces laws and judgments. In this wake, music is discovered as a powerful legal teaching tool.
\end{abstract}

Keywords: Law. Music. Communication. Optimization Teaching.

\section{Introdução}

O humano é um ser de interação. É por meio da interatividade que se evolui buscando a suprema felicidade. No exercício da interatividade surge a comunicação e, por consequência, o ensino. Para a comunicação obter seu êxito, modificando a realidade dos sujeitos da comunicação (possibilitando, assim, a evolução humana), o ato comunicativo deve ser, sobretudo, educativo, já que só haverá uma reação à comunicação se houver o convencimento do destinatário da comunicação. A partir do efetivo aprendizado, ou seja, do aprendizado legítimo, é que a mensagem proferida produz o seu efeito, justificando os atos que serão feitos na realidade. Daí a importância da educação e do ensino otimizado nas mais variadas áreas, viabilizando que o ser humano continue na sua constante transcendência.
E qual seria a ligação do Direito com a faceta da natureza humana ora consignada? Esta é a primeira problemática deste estudo. Aprioristicamente, à guisa de hipótese, supõe-se que o Direito, instrumento de regulação da liberdade nas relações com vistas ao bem comum, retrata as pessoas e a sociedade que o produz. E para retratar os seus produtores, o sistema jurídico também é alimentado por informações e reage a estas informações. Logo, o Direito seria um sistema comunicativo. Por consequência, o destinatário das informações emanadas pelo Direito (pessoa humana integrante de uma sociedade) deve, para acatar a coerção à sua liberdade, se convencer da necessidade do respeito ao Direito. Eis que novamente entraria o ensino e as metodologias pedagógicas. Só estes teriam a capacidade de efetivamente convencer os seres humanos que o respeito ao Direito contribuirá na busca da felicidade. 
Mas diante do levantamento desta hipótese urge uma nova problemática a ser respondida: qual seriam ferramentas úteis para otimizarem o ensino jurídico, ou seja, para efetivamente convencerem as pessoas da necessidade de se respeitar o Direito? Ora, se são os próprios humanos os produtores do Direito, parece ser coerente que as ferramentas a serem utilizadas sejam ferramentas também humanas. Neste contexto, seriam as artes, especialmente a música, expressões humanas aptas a serem utilizadas no ensino jurídico como ferramenta de otimização? Aparentemente, as artes, e para os fins deste trabalho, a música, por também serem produções humanas, podem cumprir o papel de compreender o Direito, bem como de interpretá-lo, inclusive criticamente, para aperfeiçoá-lo. Daí a suspeita que a utilização da música, com toda harmonia nela contida, poderá auxiliar o ensino do Direito.

É no diapasão que foi aqui lançado em prolegômenos que este estudo se desenvolverá, respondendo as indagaçõesproblemas na mesma ordem em que foram propostas, tudo com a finalidade de proporcionar ao leitor deste trabalho um coerente raciocínio sobre a temática. Assim, espera-se que a pesquisa à doutrina consiga efetivamente confirmar as hipóteses levantadas e que o resultado desta comunicação contribua para a evolução do ensino jurídico às vezes tão fadado à mera repetição legal.

\section{Desenvolvimento}

\subsection{Das Considerações Filosóficas}

Toda pessoa humana busca evoluir em busca do absoluto. Quer chegar até o fundo, até àquela fonte onde tudo jorra. Daí a sua natureza filosofante da existência humana. Quanto à existência, recorrendo a etimologia, tem-se que o prefixo "ex" remete a algo exterior, isto é, de fora. Isto leva-nos a concluir que durante a "ex-istência" humana, ou seja, durante a vida, estamos sempre a interagir com o que se situa fora de nós. Assim, o humano pode ser considerado algo aberto, já que vive em um eterno relacionamento com os demais seres humanos, com a natureza e com Deus. A este complexo fenômeno de interatividade dá-se o nome de transcendência. ${ }^{1}$

A transcendência, então, é o retrato mais ínsito à condição humana. Transcendemos quando nos apaixonamos, quando jogamos futebol, quando assistimos um filme, quando ouvimos uma música ou lemos um livro, quando cultivamos uma horta, quando rezamos, quando nos confraternizamos, enfim, transcendemos sempre que agimos em busca da felicidade.

Nota-se que a transcendência então é ligada à liberdade e ao desejo, já devemos ser livres para nos contatarmos com aquilo que nos dá a sensação de plenitude. Eis que nasce outro componente inerente ao fenômeno da transcendência: a valoração, já que estipulamos valor àquilo que nos faz bem. Assim, a espécie humana inova e também valora, ou seja, o valor então é algo intrínseco a espiritualidade humana. Reale (1994, p.161) explica a ligação entre liberdade e valoração:

Há possibilidade de valores porque quem diz homem diz liberdade espiritual, possibilidade de escolha constitutiva de bens, poder de síntese com liberdade e autoconsciência [...] O valor é dimensão do espírito humano, enquanto este se projeta sobre a natureza e a integra em seu processo, segundo direções inéditas que a liberdade propicia e atualiza.

O espírito humano, por ser livre, modela a natureza, estabelece formas de convivência, forma o cabedal da cultura por intermédio dos seus valores. ${ }^{2}$ Todo bem cultural só é por meio do seu dever ser, tudo isto construído pelo ser humano à sua imagem e semelhança no infinito processo da transcendência. A doutrina estrangeira confirma que a valoração faz parte da essência humana:

A fundamentação ontológica adoptada pelo objectivismo axiológico parte da contemplação da referencialidade dos valores a um sujeito. Estas encontram o seu ponto de referência ôntico na própria natureza espiritual do homem. São como pontos cardeais por que se orienta toda a atividade espiritual e moral do homem. Este, o homem, aspira a uma realização das suas possibilidades neste sentido, a uma efectivação da sua Ideia, à perfeita consumação da sua própria essência humana. Esforça-se por se elevar da sombra para a luz, do vale para as cumieiras da sua natureza. E os marcos que lhe indicam este caminho para as culminâncias da hominidade são os valores espirituais. Orientando-se por eles, adoptandoos como norma para o seu querer e agir, o homem realiza a sua essência. (HESSEN, 1974, p.101-102).

No processo evolutivo humano, o mesmo transcende em busca do que os gregos estimavam ser o bom, o belo e o verdadeiro. Neste eterno percurso, as pessoas humanas, ao se relacionarem, se comunicam. Faz parte da natureza evolutiva do homem a troca de informações com vistas ao conhecimento e alcance de algo melhor. É o que se encontra na lição de Juan E. Diaz Bordenave (1982, p. 9): “A comunicação é uma necessidade básica da pessoa humana, do homem social". Comunicamo-nos o dia todo, desde o bom dia até o boa noite, passando pela leitura do jornal, pela conversa na fila do banco, pelas reuniões com os colegas do escritório, pelos telefonemas, pelas mensagens em redes sociais, pelos e-mails... Assim evoluímos!

Para uma comunicação ser eficaz, Eugene Hartley e Ruth Hartley afirmam serem necessários quatro fatores: "1) $\mathrm{O}$ comunicador - a pessoa que inicia o processo; 2) a pessoa que recebe a comunicação, isto é, o destinatário; 3) o conteúdo da comunicação - que pode ser chamado o comunicado; e 4) o efeito logrado pela comunicação" (HARTLEY; HARTLEY, 1972, p.37). Veja o seguinte exemplo:

O velho artesão de Petrolina mostra a seu filho como se faz uma carranca de barro. O menino pega um pouco de barro

1 Para um aprofundamento sobre a transcendência humana, confira-se: Leonardo Boff (2009).

2 Reale (1994) define cultura como tudo que o homem realiza na história e objetivação de fins especificamente humanos. Logo, o Direito pode ser considerado a arte, a serviço desta cultura. 
e tenta fazer o mesmo que viu fazer. O menino pergunta, o velho responde. O velho corrige, aprova, mostra. Meses depois, o menino leva para a feira seus primeiros trabalhos de artesão. (DIAZ BORDENAVE, 1982, p.35).

De pronto, facilmente verifica-se os quatro fatores da comunicação no exemplo dado: o velho artesão (comunicador); seu filho (destinatário); o ensinamento (conteúdo) e a ida à feira pelo menino (efeito). Mais precisamente sobre o efeito da comunicação, pode se afirmar que "a comunicação se verifica com êxito quando o efeito produzido pelo comunicado é o efeito pretendido pelo comunicador" (HARTLEY; HARTLEY, 1972, p.73). No singelo exemplo, a ida do menino à feira apresentar o trabalho demonstra que o ensinamento do comunicador surtiu efeito.

Mas o que ainda se depreende da presente lição é que as pessoas se transformam e modificam a realidade que os rodeia por meio da comunicação. A troca de experiências, ideias e sentimentos, em um sistema comunicativo efetivamente aberto, permite o constante crescimento seguindo um procedimento que passa pela interação com os outros e com o meio ambiente, pela valoração daquilo que é evidenciado no transcorrer desta interação, pela incorporação (ou não) deste valor e pela reação à incorporação na realidade concreta. Desta forma, transmitindo padrões e valores, "a comunicação oferece ao indivíduo referências pelas quais ele pode orientar o seu comportamento" (HARTLEY; HARTLEY, 1972, p.2728).

Têm-se, então, que é imprescindível ao homem o exercício da sua comunicação, pois, após receber uma informação e refletir sobre a mesma, haverá condição de um posicionamento mais lúcido do ser social, gerando um comportamento humano adequado. Trata-se do seguinte movimento: a pessoa recebe uma informação, reflete sobre a mesma e, a partir desta reflexão, age no mundo concreto em um processo contínuo de crescimento. Assim, a pessoa vai se engrandecendo em sabedoria e a sociedade vai ganhando em solidez. Por isso é que "[...] a informação, na sua fundamentação subjetiva, ampara o homem na perspectiva de sua vida individual, permitindo o desenvolvimento integral de sua personalidade" (CARVALHO, 1999, p.56). É a mudança do mundo concreto a partir da recepção de uma informação e da maturação da mesma.

A partir do que se encontra mencionado, o que já é passível de afirmação é que o ser humano é um ser autopoiético. Autopo(i)ético, segundo a inspirada expressão de Guerra Filho (2013), que deve ser interpretada como sendo a característica do ser humano se utilizar das mensagens advindas das artes para se progressivamente se auto reproduzir em evolução. As artes podem ser entendidas como sendo a música, o teatro, o cinema, a literatura, etc., já que por todos estes meios se transmite informações e valores. São todos meios de comunicação e, portanto, por seus meios pode-se buscar a mudança em evolução inata ao homem.

Aqui parece ser o momento oportuno para ser destacada a importância do ensino para o desenvolvimento humano. Comunicação e conhecimento são conceitos siameses desde a maiêutica socrática e, por meio deles, educa-se, capacitando os seres humanos para a resolução dos eventuais problemas urgidos no mundo vivo. Luck (1994, p.85) vai ao encontro do que é proposto neste trabalho:

A educação tem por finalidade contribuir para a formação do homem pleno, inteiro, uno, que alcance níveis cada vez mais competentes de integração das dimensões básicas - o eu e o mundo - a fim de que seja capaz de resolver-se, resolvendo problemas globais e complexos que a vida lhe apresenta, e que seja capaz de, produzindo conhecimentos, contribuir para a renovação da sociedade e a resolução dos problemas com que os diversos grupos sociais se defrontam.

Com efeito, por intermédio do processo educativo, formase o conhecimento necessário para a resolução dos problemas urgidos das relações inter-indivíduos e inter-grupos e subgrupos. E a educação é fruto de muita comunicação, no que pode-se chamar de processo comuni(edu)cativo.

A partir do que se encontra consignado, já se pode estabelecer a primeira premissa deste trabalho: Que o ser humano, para içar à sua plenitude, transcendendo e valorando, faz uso do processo comunicativo que ensina e, a partir do ensinamento, os homens procedem a modificação do mundo concreto.

Já fazendo a transição para o próximo capítulo, esta condição intrínseca à pessoa humana, de ser transcendental, é o que dá sentido a história do Direito, verdadeiro instrumento criado pelo espírito humano para organização, tutela e realização de valores evidenciados pela natureza humana individual ou pelo transcorrer de sua experiência social, conforme será tratado a seguir. ${ }^{3}$

\subsection{Do Direito}

Foi tratado acima que o ser humano, por sua natureza transcendental-comunicativa, valora. E nada é mais imbricada à personalidade humana do que a proteção dos bens já evidenciados como valores e a ação voltada para busca livre de novos bens valiosos. E qual seria o instrumento, criado pelo próprio ser humano, que pode proteger e até mesmo realizar os valores evidenciados pela natureza humana individual ou pelo transcorrer de sua experiência social? O Direito. Correta é a antiga assertiva de Roberto de Ruggiero quando ele trata o Direito como subproduto da vida em sociedade e "como criação do espírito humano; criado pelos homens, aos homens se destina, regulando as suas ações e dirigindo-as ao fim supremo que é a realização do bem". (RUGGIEIRO, 1934,

3 Neste sentido, Jucá (2006) aduz que é preciso se considerar, em princípio, que o Direito tem natureza instrumental, é fruto da construção social, portanto, guarda afinidade estreita e profunda com a sociedade que o produz, sua estrutura é organização, marcando-se destarte, pelo condicionamento histórico, no processo desta sociedade. 
p.21).

Assim, o Direito acaba por ter ligação direta com as atividades do espírito humano que se realiza no plano da natureza, afeiçoando-o a sua imagem, afeiçoando o ser ao dever ser (REALE, 1994). Por isto é que o Direito deve ser visto sob o prisma de uma concepção humanista, pois o ser humano é o valor fonte dos bens que serão os objetos que o Direito irá garantir. ${ }^{4}$

Nas inimagináveis situações que se evidenciar algo necessário para o pleno desenvolvimento individual e social das pessoas, o Direito estará de portas abertas para albergar a exigência surgida no transcorrer do seu caminho. Hessen (1974, p.104) ensinou que os valores que orientam o esforço e a ação da pessoa, e que se apoderam da sua alma, não se inventam, mas se descobrem "[...] como as estrelas que ao anoitecer vão aparecendo no firmamento, assim eles vão surgindo sobre a nossa cabeça com o progresso da Cultura e vão entrando no campo visual do homem".

Este é o trecho do trabalho mais adequado a falar sobre a influência do momento histórico na descoberta dos valores, e, por consequência, das suas tutelas pelo Direito. O homem é uma realidade histórico-social. E conforme o momento do mundo ele reflete os respectivos padrões culturais. Assim, o Direito passa a ser um fenômeno histórico-cultural, que carrega as nuances e as particularidades históricas de um tempo e de um espaço.

O Direito, portanto, acompanha concomitantemente a transcendência humana, o que resulta na assertiva de que o Direito deve se utilizar dos resultados obtidos em pesquisas realizadas por outras áreas do conhecimento, tais como a antropologia, a psicologia, a sociologia e a filosofia, a economia, a ecologia, e de todos os outros sistemas, dentro de um mecanismo denominado zetética. ${ }^{5}$

Oprocesso zetéticoécomouma “osmose" de conhecimento, e a transição de um sistema epistemológico para o sistema jurídico é feita por intermédio da comunicação, em regra, pela práxis política, ${ }^{6}$ onde o Direito é "irritado" pelas informações advindas de outros ambientes e, ao serem interpretadas, se evidenciarem valores, podendo ser albergadas pelo sistema jurídico ou não. Nota-se que aqui também se tem um comunicador e um destinatário; têm-se um conteúdo e buscase um o efeito. Veja que o Direito também é autopo(i)ético, tal como o ser humano, já que também se auto reproduz na busca do aperfeiçoamento conforme as necessidades do momento histórico vão se desenhando no processo comunicativo. E, para este trabalho não ser carimbado como ingênuo, conforme as ideologias ${ }^{7}$ disseminadas por quem está no aparelhamento do poder, ou seja, com Francisco Pedro Jucá, quem encontrase investido no Estado... (JUCÁ, 2010).

Imperioso para o contexto que se pretende expor neste estudo é discorrer sobre a legitimidade do Direito, que exige que o mesmo seja, sobretudo, Justo. E esta exigência passa pela necessidade da ordem legal venha ser aceitável pela sociedade. Só assim tal ordem surtirá efeitos e gerará a pacificação social pretendida. Para Grau (1988) haverá legitimidade quando ocorrer adequação entre o comando nela consubstanciado e o sentido admitido e consentido pelo todo social, a partir da realidade coletada como justificadora do preceito normatizado. Somente com a legitimidade da norma, que passa pelo crivo dos seus destinatários como sendo justa, é que haverá a coesão em dada organização social criando condições de efetiva adesão e conformidade, gerando pacificação social.

Neste sentido, fica demonstrada a indissociável ligação entre Pedagogia e Direito. É que o Direito deve, para cumprir sua função social de pacificação, ser considerado Justo e, para ser considerado Justo, o Direito, mormente as leis e as decisões judiciais - conteúdo - devem convencer os destinatários da razão de suas existências. E este processo de convencimento dos seres humanos nada mais é que um processo edu(comuni) cativo, onde os homens - destinatários - se convencem que o comportamento ditado pelo Direito - comunicador - é o melhor a ser tomado no campo social - efeito. Assim explica Longo (2008, p.199), sobre o papel educativo, inclusive do Direito, perante o ser humano na sociedade:

É um processo de formação do homem, que faz com que alguém se conscientize de sua importância no grupo social, por menor que seja ou lhe pareça, e que exerce sua função social de participação no mundo que vive, a fim de que,

4 Já estruturando a ideia central deste trabalho, supondo-se que a música é produto do ponto mais recôndito da alma humana, não seria ela uma ferramenta de concretização do ensino do Direito? Ora, se o Direito se destina aos seres humanos, a música, humana que é, facilita a compreensão do Direito numa verdadeira simbiose que será melhor explorada a seguir.

5 Leonardo Boff (2003), em busca de consenso mínimo entre os humanos para salvar o mundo, propõe a ética holística juntamente como a ética do cuidado, a ética da solidariedade, a ética da responsabilidade, a ética seria a capacidade de detectar os inter-retro-relacionamentos de tudo com tudo. Exemplo: Economia, gestão e cálculo tem a ver com filosofia, física, arte e religião. Nada existe justaposto ou desvinculado. Nota-se, então, que a ética holística tem identificação com a zetética e, portanto, é perfeitamente aplicável ao Direito.

6 É incontestável a atuação da Música na Política. Tanto é que, no período de eclipse democrático ocorrido no Brasil a partir de 1964 , Chico Buarque cantava na música Apesar de Você: "Hoje você é quem manda / Falou, tá falado / Não tem discussão/ [...] /Apesar de você / Amanhã há de ser / Outro dia / [...]" (BUARQUE, 1970). E invejava a garra dos portugueses que foram às ruas na Revolução dos Cravos de 1974, quando cantou na canção Tanto Mar: "Sei que está em festa, pá / Fico contente / E enquanto estou ausente e / Guarda um cravo para mim / Eu queria estar na festa, pá / Com a tua gente / E colher pessoalmente / Uma flor no teu jardim / Sei que há léguas a nos separar / Tanto mar, tanto mar / Sei, também, que é preciso, pá / Navegar, navegar / Lá faz primavera, pá / Cá estou doente / Manda urgentemente / Algum cheirinho de alecrim” (BUARQUE, 1975).

7 Dmitri Shostakovitch (apud MORAES, 1985, p. 48) já afirmou: "Não há música sem ideologia. Os mestres antigos tinham consciente e inconscientemente uma orientação política. A maioria deles apoiava naturalmente o domínio das classes superiores". E por aqui Cazuza cantou: "Meu partido / É um coração partido / Minhas ilusões / Estão todas perdidas / Os meus sonhos/Foram todos vendidos / Tão barato que eu nem acredito / Ideologia / Eu quero uma para viver". 
mais que tudo, tenha a possibilidade de aprender a lição autoconstrutora, diuturna progressiva e sempiterna de fazerse humano.

O papel do jurista, então, se funde ao do pedagogo, já que ambos ensinam paradigmas comportamentais para a condução humana. Ambos pretendem educar, cada um à sua maneira, evidentemente. As leis formam hábitos, ${ }^{8}$ disciplinam interesses, despertam virtudes, mas elas só realizarão a sua função de ordenação social com a conscientização de cada um por intermédio do ensino, que gera um engrandecimento pessoal controlador dos excessos nas liberdades individuais em prol do bem coletivo. Troca a felicidade do homem pela felicidade dos homens.

Este processo de evolução ocorre dentro de cada ser humano, por meio da reflexão. Não basta a apresentação da lição, é preciso que se repense o ensinamento proposto e, a partir daí, haja uma acomodação consciente das moléculas da liberdade que sempre estão em ebulição. Por esta razão que o Direito deve ser humano, devendo tocar os caracteres mais autênticos da essência humana, pois só assim haverá sua aceitação e se alcançara a bonança almejada. E o ensino do Direito deve se utilizar de ferramentas que efetivamente atinjam o interior humano, local onde acontece este fenômeno legitimador da coerção imposta pelo Direito.

Diante de tudo que foi exposto, indaga-se: será que a Música pode ser uma ferramenta útil para o ensinamento jurídico, auxiliando da conscientização e na consequente pacificação? É o que será discorrido a seguir.

\subsection{Da música e sua ligação com o Direito}

Se o Direito deve ser humano, parece que as ferramentas para sua consecução também devem ser humanas ao ponto de alcançar o objetivo de pacificação dos indivíduos em grupos e subgrupos, ou seja, em sociedade(s). Desde já vale a pena expor que a pacificação social, fruto da imposição (e exposição, dentro do contexto trabalhado neste estudo) de um Direito-Justo, possui uma ligação umbilical com um dos componentes da música: a harmonia. Em um sentido amplo, a harmonia pode ser considerada como a condição que mantém unido, em detrimento de oposições, elementos contrários (TOMÁS, 2002). Esta condição harmônica (ou até mesmo, em muitas vezes, "des-harmônica") é encontrada na música, que reúne notas musicais opostas em um todo coeso, e no Direito, que resolve conflitos de interesses opostos, mantendo a sociedade coesa. E o que é decisivo para levar o Direito a manter a sociedade harmônica? $\mathrm{O}$ ensino jurídico, pelos motivos já expostos.

Mas a ligação entre música e Direito não se exaure na harmonia. Ambos são criações humanas. Jota de Moraes explica que música está “onde existe a mão do ser humano, a invenção. Invenção de linguagens: formas de ver, representar, transfigurar e de transformar o mundo" (MORAES, 1985, p.8). Com efeito, a música é uma realidade impregnada na vida das pessoas, senão vejamos:

A ligação entre música e ser humano se inicia no acalanto da mãe. Aliás, existem pesquisas que dão conta que a criança já sente a musicalidade no ritmo do coração da gestante quando ainda está no útero materno (JEANDOT, 1997). Quem nunca se deparou com um bebê batendo com a colher na mesa repetidamente? Também não é raro encontrar uma criança que mal fala cantarolando alguns versinhos. Continuando, vem a dança com a namorada na adolescência, utiliza-se a música como protesto na transição para a fase adulta, escolhe-se as músicas para tocar no casamento, canta-se o hino do seu time de futebol ou brada-se a música da respectiva torcida. Até a marcha fúnebre é musicalizada. Esta é a prova que a música acompanha o ser humano por toda vida.

Logo, constata-se que música e ser humano caminham lado a lado. É "co-movente". Aquela é manifestação, expressão, sublimação, catarse deste. Revela-o. Modifica-o. Daí ela se mostra essencial para o Direito, já que este também caminha lado a lado do ser humano. Desta forma com a sua utilização pelo Direito haverá efeitos sociais benéficos, eis que se trata de uma ferramenta humana que o aproximará de sua legitimidade, ou seja, de sua essência humana, ${ }^{9}$ tornando o Direito-Justo. ${ }^{10}$ Parece ter este sentido a lição de Ferraz Junior (2009, p.275), quando este discorre sobre a Justiça e as artes em geral:

O gosto artístico, contudo, como o senso de justiça em face da verdade, não manifesta simplesmente aquela qualidade e aquele talento. Gosto e senso de justiça, enquanto atividades da mente realmente culta, somente vem à cena quando a consciência da qualidade e do talento ou o sentido do justo se acham plenamente difundidos, só então sendo o belo e o justo facilmente perceptíveis. Isto põe o jurista e o artista no mesmo domínio público. [...]. Ambos são, no sentido próprio, inexoráveis humanistas, homens que sabem como preservar, admirar e cuidar das coisas do mundo, sem a elas se escravizarem. No recôndito do humanismo está o sentido da beleza e da justiça. [...]. E só a existência humanista rende justiça e cria obras de arte.

A lição de Tércio Sampaio Ferraz Junior explica muito bem a ligação entre arte (aqui leia-se música) e justiça, deixando claramente consignado que só a faceta humanista produz arte (música) e rende justiça (Direito). Por isto é que o Direito deve se utilizar da humana música.

A música pode auxiliar na (i) compreensão, na (ii) interpretação e na (iii) aplicação do Direito (e de outros fenômenos sociais). Expondo os três vetores que podem ser alcançados com o auxílio da música, tem-se que:

8 Aqui vale a pena lembrar que a palavra ética, etimologicamente, deriva da expressão ethos, que por sua vez significa hábito.

9 Neste direcionamento também é o posicionamento de Alves (2006) o reflexo estético se diferencia do científico. Enquanto o reflexo científico desantropomorfiza o real através da construção de conceitos e categorias abstratos, o reflexo estético o antropomorfiza, construindo situações típicas capazes de proporcionar autoconsciência crítica do mundo sócio histórico.

10 Sobre o Direito-Justo, confira-se: Karl Larenz (1985). 
Quanto à (i) compreensão, verifica-se que o Direito, tal como a música, no aspecto cognitivo parte da compreensão de algumas abstrações tidas como valor. Este valor é explicitado tanto na norma, quanto na canção. Assim, especialmente no tocante ao aspecto cognitivo, a música que explica um valor, facilita a futura compreensão deste mesmo valor quando ele aparece no Direito. Aqui, ainda no aspecto cognitivo, é de fácil percepção a existência de uma contraprova do que foi asseverado: basta verificar o quão difícil é compreender algumas músicas e algumas leis...

Quanto à (ii) interpretação, sabe-se que a lei não esgota o Direito, como a partitura não exaure a música. Interpretar é recriar, ${ }^{11}$ pois as notas musicais, como os textos de lei, são processos técnicos de expressão, e não meios inextensíveis de exprimir. Aplicar a exegese da lei jurídica é exprimi-la, não como uma disciplina limitada em si mesma, mas como uma direção que se flexiona às sugestões da vida. Daí que a associação entre Direito e Música permite ao estudioso e ao operador do Direito um papel mais ativo, flexível, perspicaz e atento à dinâmica que caracteriza e torneia as relações intersubjetivas. Aliás, segundo Willis Santiago Guerra Filho, a filosofia e a ciência, quando fundida com a poesia (leiase, aqui, fundida com a música), torna-se princípio ativo e regenerador do pensamento, dirigindo-o respectivamente, para o bem, o verdadeiro e o belo (GUERRA FILHO, 1999).

A utilização da Música também parece ter espaço na fundamentação das decisões judiciais. Como a música é manifestação cultural e relata feitos sociais, a utilização de certas canções em decisões judicial pode ser importante para o entendimento do mandamus e para o convencimento das partes interessadas na justiça da decisão e da necessidade de cumpri-la. Trata-se de verdadeira "pró-vocação" realizada pela mensagem passada pela música, já que a pessoa que se encontra conhecendo previamente a mensagem musical se encontra pré-disposta a acatar o contexto exposto. Neste diapasão, encontra-se a lição de Niklas Luhmann, quanto este assevera que as artes funcionam como prognósticos que se antecipam a evolução social, tornando-se, frequentemente sua mola propulsora (SCHUWRTS; MACEDO, 2012). Desta forma, a música pode possuir função importante também na (iii) aplicação do Direito.

\subsubsection{Música e Ensino Jurídico}

Como visto, a música pode ser utilizada na compreensão, na interpretação e na aplicação do Direito. Logo, especialmente, por ser ferramenta de compreensão e interpretação do Direito, ela também pode ser útil no ensino jurídico.

Mas a relação entre música e ensino vem sendo explorada há muito tempo: Etimologicamente, o termo música tem ligação com a expressão grega mousiké, que, por sua vez, é ligada ao termo mousa, que no vernáculo são as musas. E as musas eram consideradas as deusas da educação, conforme explica Tomás (2002). Aliás, em sintonia com o que vem se desenhando neste estudo, a autora ainda expõe que a relação entre a música, a harmonia e a pedagogia do ethos, se irradia para toas as atividades educacionais, por se mostrar poderoso instrumento de efetivação do ideal.

Com efeito, em coerência com o que já foi exposto, para a efetivação no conteúdo comuni(edu)cativo, em especial a transmissão do ethos ideal, por meio da música, gera a harmonia tão buscada pelo Direito.

Veja que não se trata do ensino na modalidade que outrora Paulo Freire denominou de educação bancária (FREIRE, 1984), onde existem depósitos de informações e simples memorização de dados. Nesta perspectiva, não haveria a transcendental evolução humana tratada nas palavras iniciais deste trabalho. Pelo contrário, a educação repetitiva, meramente transmissora, propicia a dominação, já que serviria de mero eco da(s) ideologia(s) do(s) grupo(s) dominante(s). ${ }^{12}$

No vetor ora apresentado, com Wolkmer e Caovilla (2014, p.95), é "necessário o despertar o espírito crítico, para que possamos nos libertar da tradição e abrir espaço para o recebimento do novo, do plural, do intercultural, ampliando a interpretação e operacionalização do Direito de acordo com a realidade social". Assim, a partir do ensino jurídico praticado nesta perspectiva é que haverá um Direito correspondente a pluralizada expressão humana, fruto da diuturna transcendência.

Aqui entra a criatividade externalizada pelo lúdico e a beleza mostrada pelo estético contido nas músicas, pois, ao mesmo tempo, com sutileza e força, (i) impregna na sociedade os paradigmas axiológicos fundantes do Direito, facilitando assim a sua compreensão e (ii) fomenta na mesma sociedade as perspectivas interpretativas que podem ser dadas ao Direito. E o ensino jurídico trabalhando com este tipo de exposição do saber, contribui para "arquitetar uma proposta ética de reconhecimento e respeito da enorme diversidade de visões no mundo" (CAOVILLA; WOLKMER, 2014, p.97), legitimando o Direito, tornando-o Justo e, consequentemente, harmonizando a sociedade.

No processo comuni(edu)cativo jurídico a reflexão musicalizada, pela eclética que a caracteriza, certamente proporciona uma visão multifacetada da sociedade, proporcionando "a conscientização do respeito ao outro que possibilitará a harmonia precisa para a liberdade de cada um e a consequente realização do Direito" (LONGO, 2004, p.47).

11 Quanto ao processo hermenêutico, ou seja, quanto ao processo de procura e auto superação, vale a pena citar a música Caçador de Mim, de Milton Nascimento (1981): "Por tanto amor / Por tanta emoção / A vida me fez assim / Doce ou atroz / Manso ou feroz / Eu, caçador de mim / Preso a canções / Entregue a paixões / Que nunca tiveram fim / Vou me encontrar / Longe do meu lugar / Eu, caçador de mim / Nada a temer senão o correr da luta / Nada a fazer senão esquecer o medo / Abrir o peito a força, numa procura / Fugir às armadilhas da mata escura / Longe se vai / Sonhando demais / Mas onde se chega assim / Vou4 descobrir / O que me faz sentir / Eu, caçador de mim".

12 Infelizmente, é exatamente o que se constata nos dias atuais. 
Confira-se, a seguir, alguns exemplos de músicas que possuem ligações com o Direito, aproveitando para se verificar como sua utilização poderia otimizar o ensino jurídico, por meio da conscientização das premissas apontadas:

Na música Cidadão (1992), de Lucio Barbosa, mas que ficou conhecida na voz de Zé Geraldo, encontra-se fortes ensinamentos sobre Direito do Trabalho, especialmente sobre a origem do in dúbio pró-operário. Também nota-se uma mensagem sobre o pré-conceito discriminatório contido na expressão "ou tá querendo me roubar?". Seguem os versos iniciais:

Tá vendo aquele edifício moço?

Ajudei a levantar.

Foi um tempo de aflição, eram quatro condução duas pra ir, duas pra voltar.

Hoje depois dele pronto

olho pra cima e fico tonto,

mas me chega um cidadão

e me diz desconfiado:

Tu tá aí admirado ou tá querendo roubar?

$[\ldots]$

Veja que a música propicia uma reflexão sobre a discriminação, sabidamente vedada pela Constituição Federal. Com a exposição da música, certamente haverá maior facilidade para o docente demonstrar a necessidade de o Direito intervir nos casos discriminatórios e em casos de exploração no trabalho, dada a notória e múltipla hipossuficiência do empregado.

Já na música Admirável Gado Novo, de Zé Ramalho (1979), existe forte crítica ao estado de alienação da sociedade, composta por seres humanos massificados como se fossem um enorme rebanho bovino. E a partir da interpretação da mensagem da música, verifica-se que o Direito, ao invés de ser instrumento de ordenação, encontra-se sendo utilizado como instrumento de dominação. Faraco Neto e Ruiz (2012), aliás, fazem um estudo interessante da mensagem desta música que vale a pena ser conferido. Na apreciação da primeira estrofe da música já se percebe o sentido de seu conteúdo:

\footnotetext{
Vocês que fazem parte dessa massa

Que passa nos projetos do futuro

É duro tanto ter que caminhar

E dar muito mais do que receber

E ter que demonstrar sua coragem

A margem do que possa parecer

E ver que toda essa engrenagem

Já sente a ferrugem the comer

Êh, oô, Vida de gado

Povo marcado Êh, povo feliz!

$[\ldots]$
}

Partindo para o sertanejo de raiz, na canção Filho Adotivo (1981), Sérgio Reis e Renato Teixeira, retratam, por meio do abandono moral narrado, os Direitos dos Idosos. No trecho abaixo nota-se facilmente o que é ora asseverado:

$[\ldots]$

Hoje estou velho

Meus cabelos branquearam
O meu corpo está surrado

Minhas mãos nem mexem mais

Uso bengala

Sei que dou muito trabalho

Sei que às vezes atrapalho

Meus filhos até demais

Passou o tempo

E eu fiquei muito doente

Hoje vivo num asilo

E só um filho vem me ver

$[\ldots]$

Ainda na música Filho Adotivo, existem trechos em que se pode explorar conceitos de Direito de Família, especialmente da paternidade responsável e da desbiologização da paternidade, já que a canção ainda fala que o Pai (que depois foi abandonado em um asilo), mesmo passando por dificuldades, criou sete filhos ao ponto de eles terem se formado academicamente, bem como fala que foi o filho adotivo que lhe deu amparo no final da vida. Aqui também será salutar ao ensino jurídico a apresentação desta música quando do ensinamento dos conceitos abordados.

Chico Buarque, na sua Homenagem ao Malandro (1978), canta em suave ritmo a teoria criminológica da Associação Diferencial. Salutar na aula de Criminologia, o professor utilizar-se desta canção para explicar o perfil do "novo" criminoso, já que "aquela tal malandragem já não existe mais". Confira-se o início da música:

Eu fui fazer um samba em homenagem

À nata da malandragem

Que conheço de outros carnavais

$\mathrm{Eu}$ fui à Lapa e perdi a viagem

Que aquela tal malandragem

Não existe mais

Agora já não é normal

O que dá de malandro regular, profissional

Malandro com aparato de malandro oficial

Malandro candidato a malandro federal

Malandro com retrato na coluna social

Malandro com contrato, com gravata e capital

Que nunca se dá mal

$[\ldots]$

Shecaira (2013, p.172) ensina que a Teoria da Associação Diferencial parte da ideia que "o crime não pode ser definido como disfunção ou inadaptação de pessoas de classe menos favorecidas, não sendo ele exclusivamente destas". E nos casos de crimes do colarinho branco, como os delinquentes possuem respeitabilidade social, torna-se mais difícil as suas punições. Veja a plena identificação entre a disciplina e a música, podendo ser esta utilizada na compreensão e na interpretação daquela.

Nas entrelinhas da composição da música Construção (1971), novamente recorrendo a elevada inspiração de Chico Buarque, pode-se interpretar uma crítica a teoria do mínimo existencial e à condição de alienação da sociedade. A música canta a rotina coisificada - " [...] subiu a construção como se fosse máquina" - de um operário da construção civil que acaba morrendo em um acidente de trabalho. Em que pese a crítica à condição humana contida em todas as estrofes da 
música, são nas últimas três que se evidencia a relação entre a alienação humana e a crítica à teoria do mínimo existencial e à condição humana. Veja-se:

$[\ldots]$

Por esse pão pra comer, por esse chão pra dormir

A certidão pra nascer e a concessão pra sorrir

Por me deixar respirar, por me deixar existir

Deus lhe pague

Pela cachaça de graça que a gente tem que engolir

Pela fumaça e a desgraça, que a gente tem que tossir

Pelos andaimes pingentes que a gente tem que cair

Deus lhe pague

Pela mulher carpideira pra nos louvar e cuspir

E pelas moscas bicheiras a nos beijar e cobrir

E pela paz derradeira que enfim vai nos redimir

Deus lhe pague.

Nas estrofes supratranscritas, o que se nota é que o operário agradece por ter pão para comer, por ter chão para dormir, por ter certidão para nascer e por ter concessão para sorrir; agradece porque o deixam respirar e existir; agradece ainda pela cachaça que tem que engolir, pela fumaça e pela desgraça que tem que tossir e pelos andaimes que tem que cair; ao final, agradece por morrer. Trata-se, certamente, de irônica gratidão, pela qual Chico Buarque quer demonstrar que o ser humano encontra-se em um estado de alienação tal, que se apresenta condicionado a agradecer coisas mínimas (pão, chão, certidão), ou até mesmo maléficas (cachaça, fumaça), que lhes são dadas como se fossem correspondentes à grandeza humana. Aqui cabe a crítica a teoria do mínimo existencial, ao menos na perspectiva que ela é dada atualmente, ou seja, reduzindo o mínimo existencial humano ao mínimo material vital. Tal como na música, o Estado, atualmente, oferece o mínimo para a pessoa humana manter-se viva, esquecendose da complexidade humana, que inclusive foi pincelada no primeiro capítulo deste trabalho. A pessoa humana não se restringe ao homo economicus, material, tal como trabalha a teoria do mínimo existencial, mas é também homo ludens, homo loquens, homo sapiens, homo religiosus, homo simbolicus... e toda complexidade transcendental que lhe é constituidora. $\mathrm{O}$ viés proposto da temática ora abordada não é simples de ser explicada quando do seu ensino. Contudo, é inegável que o auxílio da música o torna mais compreensível, tal como espera-se ter sido demonstrado.

Ainda quanto a música Construção, também interessante é que a sua sonoridade se apresenta em elevada dramacidade, sendo que este drama é o mesmo vivido pelo operário, e isto permite aos ouvintes da música uma maior percepção do viés crítico contido na canção.

E se Chico Buarque demonstrou, por meio da dramaticidade contida na sonoridade, a dramaticidade sofrida pelo operário, a (des)harmonia contida em muitas músicas é a mesma (des) harmonia contida na sociedade que as produz.

Procedendo a uma incursão à música internacional, em
Papa-Paparazzi (2008), Lady Gaga expõe a tensão existente entre os Direitos da Personalidade de uma pessoa pública e o direito à informação que respalda o trabalho da imprensa. $\mathrm{Na}$ letra desta música, os paparazzi se autodenominam o público. Em tradução livre: "Nós somos o público, nós estamos chegando; Liguei meu flash, é verdade, preciso daquela foto sua". Depois, já no refrão, há uma ameaça de perseguição ao cantor. Novamente em tradução livre: "Eu sou sua maior fã, vou te seguir até você me amar; Papa-Paparazzi; Baby, não há outra superstar, você sabe que eu serei sua Papa-Paparazzi; Prometo que serei gentil, mas não vou parar até aquele garoto ser meu; Baby, você será famoso, perseguirei você até que me ame; Papa-Paparazzi". Nota-se um desabafo da artista ligando a perseguição imposta pelos paparazzi ao amor doentio de um fã. A crítica ao comportamento que sufoca a intimidade e a imagem das pessoas públicas por parte dos paparazzi é tão forte que na entrega do prêmio Video Music Awards do ano de 2010, Lady Gaga fez uma apresentação ao vivo cantando e interpretando esta música. ${ }^{13}$ Começa a interpretação dançando normalmente, ao meio já utiliza uma muleta e ao final da apresentação a cantora sangra e morre aos sons de flashes de máquinas fotográficas, ou seja, representando que o artista vai perdendo a sua personalidade até a morte pela ação dos paparazzi. Inequívoca a mensagem da nocividade dos paparazzi aos Direitos da Personalidade da pessoa pública. ${ }^{14}$

Veja que em todos os exemplos pode-se passar os conceitos de forma lúdica. É a prova que se pode interpretar os conteúdos jurídicos das músicas brincando. Assim, educase levemente.

E em todos os exemplos ora trazidos, e em incontáveis outros, evidencia-se que a utilização da música no ensino do Direito irá ser de extremos benefícios, podendo se dizer que o ensino jurídico possui uma ferramenta para a realização de uma educação jurídica crítica e conscientizadora do papel de cada pessoa na sociedade: a música.

\section{Conclusão}

Em suma, diante dos questionamentos levantados como problemas a serem respondidos por este estudo, primeiramente constatou-se que o ser humano é um ser de transcendência, encontra-se sempre em evolução na contínua busca da felicidade suprema.

Neste eterno processo, as pessoas fazem uso da comunicação, já que somente por seu intermédio é que há o engrandecimento em sabedoria. Mas a comunicação só surte efeito se o destinatário da informação a incorpora. Para este fenômeno de incorporação efetivamente acontecer, o emissor da informação deve convencer o destinatário sobre o conteúdo da mensagem. É a partir do convencimento do destinatário da mensagem sobre o teor da comunicação que este vai alterar a realidade, e, consequentemente, evoluir. Eis, então, a flagrante

13 É inegável que o cinema e o teatro também auxiliam na criação, na interpretação e na aplicação do Direito.

14 Confira em: http://www.youtube.com/watch?v=j7vWWYmB9sY. 
importância do ensino para a evolução humana. Só haverá a transmissão de conhecimento por meio do processo educativocomunicativo, pois só este tem a capacidade de convencer os destinatários dos conteúdos das mensagens trocadas.

Procedida à uma sempre pertinente pesquisa à teoria geral do Direito, verificou-se que o Direito se trata de instrumento de ordenação social a partir do controle das liberdades. Logo, o Direito, inevitavelmente, é coercitivo. Para esta coerção ser respeitada, ela precisa do aceite da sociedade. E este aceite somente virá com o convencimento das pessoas que as medidas coercitivas são necessárias para a consecução do bem comum. Ora, o que se tem aqui também é um processo comunicativo, onde o emissor da mensagem jurídica (leis, sentenças, etc.) deve convencer os destinatários desta mensagem sobre o seu conteúdo. A partir daí é que haverá a modificação da realidade, pois este Direito será considerado Justo pela sociedade que passará a acatá-lo. É a legitimação do Direito. Portanto, o Direito também é educativo-comunicativo.

Mas para ocorrer a educação jurídica da sociedade, necessário é que seu processo de ensino seja instrumentalizado por ferramentas humanas. Isto porque o Direito é criado pelo homem e a ele se destina. Assim sendo, com a utilização de ferramentas humanas o ensino jurídico será otimizado, já que, ao expor o conteúdo da comunicação à sociedade, o processo de convencimento será facilitado pela pré-compreensão da mensagem já anteriormente impregnada nos destinatários pela ferramenta utilizada.

Diante deste quadro, evidenciou-se que a música seria uma destas ferramentas de otimização do ensino jurídico, já que se trata de um tipo de arte eminentemente humana, com capacidade para tocar com sutileza e força os destinatários do Direito, que passaria a ser lúdico, propiciando-lhes uma melhor compreensão e uma melhor interpretação do jurídico, fomentando a reflexão e inflamando a crítica modificadora da realidade.

\section{Referências}

ALVES, G. Cinema como experiência crítica. Uma hermenêutica do filme. In: ALVES, G. Trabalho e cinema: o mundo do trabalho através do cinema. Bauru: Praxis, 2006.

BOFF, L. Ethos Mundial: um consenso mínimo entre os homens. Rio de Janeiro: Sextante, 2003.

BOFF, L. Tempo de transcendência: o ser humano como um projeto infinito. Petrópolis: Vozes, 2009.

BUARQUE, C. Apesar de você. 1970. Disponível em: https:// www.letras.com/chico-buarque/7582/. Acesso em: 31 jul. 2019.

BUARQUE, C. Construção. 1971. Disponível em: https://www. letras.mus.br/chico-buarque/45124/. Acesso em: 31 jul. 2019.

BUARQUE, C. Homenagem ao Malandro. 1978. Disponível em: https://www.letras.mus.br/chico-buarque/45135/. Acesso em: 31 jul. 2019.

BUARQUE, C. Tanto mar. 1975. Disponível em: https://www. letras.com/chico-buarque/45178/. Acesso em: 31 jul. 2019.

CAOVILLA, M.A.L.; WOLKMER, A.C. A educação jurídica diante do novo constitucionalismo latino americano. In:
ENCONTRO NACIONAL DO CONPEDI, 2014, Florianópolis. Anais .... Florianópolis: Fundação Boiteaux, 2014. p. 93-108.

CARVALHO, L.G.G.C. Direito de informação e liberdade de expressão. Rio de Janeiro: Renovar, 1999.

CAZUZA. I. 1988. Disponível em: https://www.letras.com/ cazuza/43860/. Acesso em: 31 jul. 2019.

CIDADÃO. Intérprete: Zé Geraldo. Compositor: Lucio Barbosa. 1992. Disponível em: https://www.letras.mus.br/zegeraldo/68686/. Acesso em: 31 jul. 2019.

DIAZ BORDENAVE, J.E. O que é comunicação. São Paulo: Brasiliense, 1982.

FARACO NETO, P.; RUIZ, I.A. Mensagem da música Adorável Gado Novo: contribuição do Direito para as pessoas humanas que levam uma vida de gado, em total desrespeito aos Direitos da Personalidade. In: ENCONTRO NACIONAL DO CONPEDI, 21, 2012, Uberlândia. Anais [...]. Uberlândia: Fundação Boiteux, 2012. p. 8228-8251.

FILHO adotivo. Intérprete: Sérgio Reis e Renato Teixeira. Compositor: Arthur Moreira e Sebastião Ferreira Da Silva. 1981. Disponível em: https://www.letras.com/sergio-reis/103204/. Acesso em: 31 jul. 2019.

FERRAZ JUNIOR, T.S. Estudos de filosofia do direito: reflexões sobre o poder, a liberdade, a justiça e o direito. São Paulo: Atlas, 2009.

FREIRE, P. Pedagogia do Oprimido. Rio de Janeiro: Paz e Terra, 1984.

GRAU, E.R. Direito, conceitos e normas jurídicas. São Paulo: Revista dos Tribunais, 1988.

GUERRA FILHO, W.S. Da Epistemologia Metafisico-Teológica Medieval à Teoria dos Sistemas Sociais Autopéticos, v.1, n.1, p.177-194, 2013.

GUERRA FILHO, W.S. Introdução à filosofia e à epistemologia jurídica. Porto Alegre: Livraria de Advogado, 1999.

HARTLEY, E.L.; HARTLEY, R.E. A importância e a natureza da comunicação. In: STEINBERG, C.S. Meios de comunicação de massa. São Paulo: Cultrix, 1972.

HESSEN, J. Filosofia dos valores. Coimbra: Armênio Amado, 1974.

JEANDOT, N. Explorando o universo da música. São Paulo: Scipione, 1997.

JUCÁ, F.P. Direito e política. In: PEREIRA, A. et al. Estudos jurídicos em homenagem ao professor Silas Gonçalves. São Paulo: Scortecci, 2006. v. 1.

JUCÁ, F.P. Estado e Direito. In: MESSA, A.F.; DALLARI JUNIOR, H.A. O Direito na atualidade: homenagem ao Dr. Pedro Ronzelli Júnior. São Paulo: Rideel, 2010. v. 1.

LADY Gaga. Papa-Paparazzi. 2008. Disponível em: https://www. letras.mus.br/lady-gaga/1294629/. Acesso: 31 jul. 2019.

LARENZ, K. Derecho Justo. Fundamentos da Ética Jurídica. Madrid: Civitas, 1985.

LONGO, A. O Direito de Ser Humano. Rio de Janeiro: Forense Universitária, 2004.

LUCK, H. Pedagogia interdisciplinar. Fundamentos teóricometodológicos. Petrópolis: Vozes, 1994.

MORAES, J.J. O que é música. São Paulo: Nova Cultural, 1985.

NASCIMENTO, M. Caçador de Mim. 1981. Disponível em: https://www.vagalume.com.br/milton-nascimento/cacador-de- 
FARACO NETO, P.

mim.html. Acesso em: 31 jul. 2019.

RAMALHO, Z. Admirável Gado Novo. 1979. Disponível em: https:/www.letras.mus.br/ze-ramalho/49361/. Acesso em: 31 jul. 2019.

REALE, M. Introdução à filosofia. São Paulo: Saraiva, 1994.

RUGGIEIRO, R. Instituições de Direito Civil. São Paulo: Saraiva, 1934.
SCHUWRTS, G.; MACEDO, E. Pode o direito ser arte? Respostas a partir de direito e literatura. In: ENCONTRO NACIONAL DO CONPEDI, 21., 2012, Manaus. Anais [...]. Manaus, 2012. p.1013-1031.

SHECAIRA, S.S. Criminologia. São Paulo: Revista dos Tribunais, 2013.

TOMÁS, L. Ouvir o lógos: música e filosofia. São Paulo: UNESP, 2002. 